This is an Accepted Manuscript of an article published by Taylor \& Francis in Critical Military Studies on 15 August 2016, available online:

http://www.tandfonline.com/10.1080/23337486.2016.1217615. 


\section{Torås Kommandoplasse: Observations from a dark summit}

Much of my artistic and written practice relates to the numerous ways in which conflict produces and redefines space. This undertaking ordinarily requires a mixed methodology of visual techniques and fieldwork to reveal the hidden or obscured dimensions of militarism. As a process it is always challenging, demanding different strategies for each unique site, and more often than not is only partially successful at interpreting the nuanced and sometimes immaterial relationships between landscape, architecture, technology and militarism. Over the past six years, I have been returning to the island of Tjøme on the Oslofjord in Norway to document a recently demilitarized zone - a process which prompted me to revisit the medium of monochrome photography to describe the zone and its curious architecture. By removing colour from these landscapes and military forms, I was hoping to diffuse the distinction between the organic and inorganic, between rocks and trees, mosses, lichens and concrete, and suggest a shared, primordial materiality.

This site, which was once a Nazi artillery base and later a Cold War training facility, is a photographer's delight: a dramatic cluster of cryptic military buildings and infrastructure in a state of abject ruination, seeming to coalesce and fuse with their organic and geological surroundings. However, despite its initial visual appeal the site generates a sense of disquiet, not least because of its dark history but also because it so effectively mimics the contours of the landscape around it. Where everyday architecture proudly announces its function and cultural derivation, defensive military architecture such as this seeks to simulate and deceive - it apes the landscapes we admire and inhabit.

The images presented here are the early impressions of a remote military outpost, of military space as a 'cyclothymic animal' hibernating during peacetimes and awakening for conflict (Virlio 1994, 21), as it has during the course of the $19^{\text {th }}$ and $20^{\text {th }}$ centuries. Over six years, the site and its architecture has changed little, exhibiting what can only be described as a kind of entropic stasis, as if it had entered a realm of geological time more in line with the Larvikite granite beneath it or the tectonic shifts of the Oslofjord itself. Six years is nothing from the perspective of deep-time but it is enough to frame an obsession with the military site as more than simply the redeployment of local minerals, but as a speculative enquiry into the persistence and material transformation of violence. 
Torås Fort is a 400 acre site that lies at the heart of Tjøme, and was established as a defensive 'optical telegraph' station in 1807 , then became a heavy artillery base immediately prior to the Second World War, but was quickly captured and refortified by the Nazi invaders in 1940. With its two sizable parade grounds, barrack buildings, four large hill-top naval cannon emplacements and a complex network of tunnels in the granite hills, Torås was a facility of considerable size that somehow remained discreetly embedded in the topography of the island landscape. The dramatic undulations of Larvikite rock formations and the verdant forests of pine and oak combine to create a perfect defensible position to observe any approach by sea from the south or the surrounding islands. At the centre of the facility, is the cyclopean Kommandoplasse, a darkly imposing hill-top command centre fashioned almost entirely out of poured concrete and crowned with an abrupt square platform under which soldiers would engage in 360 degree panoptical observation. Created to mimic the dramatically rounded contours of the local geology, this synthetic peak is a travesty of human architecture, built to simultaneously impose authority on the surrounding island which was occupied by the Nazis during the Second World War, and allow a panoramic view of the Oslofjord and the regional archipelago of islands beyond. The principal focus for the base commander, however, would have been the Worlds End (Verdens Ende), a finger of land and a scattering of small islands pointing out to the open gulf and the route of any counterinvasion by sea. Around Torås, the granite formations are both alien and anthropomorphic in appearance: unlike much of Norway, the Larvikite landscape is almost human in scale, with sympathetic hollows that inspire thoughts of rest, shelter or even habitation, and traversable peaks that are easily managed in short leaps. And yet, Larvikite's giant, smoothly amoebic surfaces glisten in the sun like vast silicate organisms trapped in temporal stasis, forever plunging into the black, cold, ocean.

Despite its imposing stature and the silent readiness of its massive Bofors cannons, records at the municipal library suggested that Torås Fort saw little action during the war, an outpost animated only by mundane routines and pointless exercises (Sørlie 2009). After liberation by the Allies in 1945, the base reverted to use by the Norwegian military, and during the Cold War the four Bofors cannons continued to point out to sea, an absurd gesture of defiance against an improbable Soviet invasion from the south. Norwegian soldiers and special forces units continued to be trained here until 1999, when the site was finally moth-balled, 
remaining under care-and-maintenance by the military for a further decade before being released back to the municipality in 2010.

The impulse to return again and again to Torås and the Kommandoplass is driven by a desire to understand the relationship between the ancient plutonic geology and Nazi military modernism - where function does not so much follow form as follow the requirement to physically embody the millennial expectations of the Reich. While it is difficult not to marvel at the improvised architecture and feats of rapid construction by the Organisation Todt (the engineering wing of the Nazi state apparatus), the site is also a catastrophe of geological redeployment, where most of the building materials were brutally extracted from gaping granite quarries still visible within the compound. Concrete is the abiding material at Torås, blasted from the nearby landscape, pulverized and mixed with cement to form a plastic and fluid medium. Granite returns once more, albeit temporarily, to its protean viscous state. Unlike much of Britain's improvised defences, which were rapidly and often poorly constructed, Nazi defences generally benefited from the uniform design, direction and supervision of a central command organisation (Hirst 2005, 209). Such was the case with Torås, which blends almost imperceptibly into the landscape and is only now showing signs of decay over seventy years after its construction. Organic life may have grown over, around and inside it, but each brutal concrete surface seems indifferent to the extremes of Norwegian weather and the rigours of time. These buildings and weapon systems may never be fully detached from the horrors of fascism, and their sheer persistence in the landscape is a sobering reminder of the architectural permanence envisioned by Nazi ideologues.

Landscape is always the unwitting recruit in any process of militarisation, and is often perceived in objectivised and strategic terms, an alternative, parallel conception of place as a realm of impending violence, subjugation and potential destruction. Battles are won and lost on the basis of how well each side understands the physical characteristics of the landscape before them, dividing and subdividing it into iconographic foci whose use and risk-value is ranked in a tactical regime within the military imagination (Woodward 2004, 104). My interest in militarised environments relates to how such a rigid interpretation of space, and the potential for destruction and death within it, can nevertheless generate possibilities for theoretical and creative analysis. Currently, we find a great deal of interest in the value of art and aesthetics as forensic tools, creatively deployed to expose abuses of power and the innumerable forgotten tragedies of conflict (Keenan and Weizman 2012). However, creative practices can also be 
employed to interpret subtler transformations that take might place within militarised environments, relating instead, to effects on natural eco-systems, individual organisms, geological processes, and the impact of conflict over much broader or deeper time-frames.

My investigations at Torås began as a photographic study, but evolved into a much more granular analysis of the site, later employing microscopic photography, moving images, narration and even fictional characters to facilitate a subjective and obsessively materialist reading of the outpost and its physical composition. This fictional reading was a recognition and a play on my own apparent 'obsession' with the site, and allowed me to extend themes beyond empirical, academic analysis into a speculative geological interpretation of violence, one in which the organic world is merely accelerating the inherent (volcanic and magmatic) violence of the inorganic. Torås represents the most abysmal transformation of the mineral world, one that will persist for centuries as the calcified expression of extreme militarism and human brutality, a dark beacon of contempt and subjugation.

The images presented here mark the beginning of the process, and represent a fraction of the output for this six-year period. I have walked the scorched granite promontories of Torås dozens of times rarely encountering anyone else. I have explored its tunnels and bunkers, its numerous gun emplacements and quarries, always anticipating a discovery that will expose the fallacy of its violent function and emasculate its seductive dominion. The apparent indifference of landscape to the violence inflicted upon it is, in fact, an almost imperceptibly slow reckoning with entropy and time, whose meaning is beyond the duration and comprehension of minds like mine.

\section{Bibliography}

Keenan, T \& Weizman, E 2012, Mengele's Skull: The Advent of a Forensic Aesthetics, Sternberg Press, Berlin.

Hirst, P 2005, Space and Power: Politics, War and Architecture, Politi, Cambridge.

Virilio, P 1994, Bunker Archaeology, Princeton Architectural Press, New York.

Sørlie, R 2019, Festung Tjøme: Tysk okkupasjon av Tjøme 1940-45, self-published. 
[Photographs to be inserted at beginning of essay with titles beneath]

[Figure 1. Torås Kommandoplasse (2012), 40 × 27 inch, c-print.]

[Figure 2. Torås Canon Emplacement (2012), $40 \times 27$ inch, c-print.]

[Figure 3. Torås Canon Emplacement No. 2 (2012), $40 \times 27$ inch, c-print.]

[Figure 4. Torås Fort (2012), 40 × 27 inch, c-print.]

[Figure 5. Torås Gun Emplacement No.1 (2012), 40 x 27 inch, c-print.]

[Figure 6. Torås Canon Emplacement No.2 (2012), $40 \times 27$ inch, c-print.] 